\title{
Autonomous responsibilities, abilities and behaviours: An appraisal of English-majored students
}

\author{
Truong Minh $\mathrm{Hoa}^{1 *}$ \\ ${ }^{1}$ Nguyen Tat Thanh University, Vietnam \\ *Corresponding author: ngutngonnguhoc91@gmail.com
}

\begin{tabular}{|c|c|}
\hline ARTICLE INFO & ABSTRACT \\
\hline $\begin{array}{l}\text { DOI:10.46223/HCMCOUJS. } \\
\text { soci.en.9.2.264.2019 }\end{array}$ & $\begin{array}{l}\text { Learner autonomy has become the prevailing theme of } \\
\text { language education for nearly four past decades, especially its } \\
\text { three constructs such as responsibilities, abilities and } \\
\text { behaviors. Thus, the current study embraced the salient traits }\end{array}$ \\
\hline Received: October $15^{\text {th }}, 2019$ & of a survey research design to scrutinize these constructs as \\
\hline Revised: December $10^{\text {th }}, 2019$ & appraised by the Vietnamese tertiary learners. The study \\
\hline Accepted: December $13^{\text {th }}, 2019$ & $\begin{array}{l}\text { recruited the participation of } 80 \text { English-majored students at } \\
\text { Hung Vuong University, Vietnam. Their appraisal was } \\
\text { elucidated by a quantitative instrument, that is, a } 28 \text {-item } \\
\text { questionnaire whose descriptive statistics were yielded by }\end{array}$ \\
\hline $\begin{array}{l}\text { Keywords: } \\
\text { appraisal, autonomous abilities, } \\
\text { autonomous behaviors, } \\
\text { autonomous responsibilities, } \\
\text { English-majored }\end{array}$ & $\begin{array}{l}\text { SPSS 22.0. The study found that a greater proportion of the } \\
\text { informants ultimately recognized their autonomous } \\
\text { responsibilities, acknowledged their autonomous abilities, and } \\
\text { estimated some autonomous behaviors both inside and outside } \\
\text { the classroom. Brief conclusion was made at the end of the } \\
\text { paper. }\end{array}$ \\
\hline
\end{tabular}

\section{Introduction}

New approaches have been always emanating in English language education, but there is still a trend somewhere to ascribe learners to passive recipients of new information, as individuals who are unable to develop the necessary skills in learning to assess and control their own progress themselves. Specifically, language education in some Asian areas including the Vietnamese context has been traditionally enacted by such a focal commission of the teachers is to dominantly deliver the knowledge to their students in place of transforming students to become independent individuals in their learning process (Dang, 2012; T. N. Nguyen, 2014; Trinh, 2005), which was profoundly empowered by the rooted Confucian perspective. In such traditional classes, learners tend to be very passive and much reliant upon their teachers for all elements of the language learning process (T. N. Nguyen, 2014) such as deciding on what to learn and how to learn through designing classroom activities, motivating the students. and providing authoritative comments on students' language performance in the classroom (T. P. T. Nguyen, 2019). However, it is imperative that teachers' and learners' roles should be urgently modified. In particular, teachers should provide students with appropriate strategies and chances for their active practice in language classrooms. At that time, under such a learnercentered pedagogy, students who become more autonomous and active have "ability to take 
charge of one's own learning" (Holec, 1981, p. 3).

In academia, learner autonomy has automatically become the most prevailing theme of almost all pedagogical agendas and conferences, receiving great concern from numerous theorists around the world (e.g., Benson, 2007; Benson, 2011; Holec, 1981; Littlewood, 1996; Wenden, 1991) for nearly four decades (Borg \& Al-Busaidi, 2012). There are some variations in defining the learner autonomy concept under varied angles from numerous authors in different contexts (Han, 2014). Initially, the pioneer Holec (1981) defines the term of learner autonomy by the four traits. First of all, learner autonomy literally pertains to the learner rather learning process. Secondly, learner autonomy is accumulated through a systematic and deliberate learning process but not innate capacity. Thirdly, learner autonomy refers to both psychology and actions of students in learning progress. Finally, it is related to students' responsibility for making decisions about strategies in their learning process. Similarly, learner autonomy indicates "a capacity and willingness to act independently and in cooperation with others, as a social, responsible person" (Dam, Eriksson, Little, Miliander, \& Trebbi, 1990, p. 102). It means that learner autonomy can happen under different interactional patterns such as with self, with teachers or with classmates. To recap briefly, inferred from these definitions, the researcher gave an emphasis on three constructs of learner autonomy, inclusive of autonomous responsibilities, abilities, and inside and outside behaviors when investigating the Englishmajored students' appraisal of their learner autonomy.

The boom of learner autonomy is gauged as one of the most eminent instructional aims and as "one of the key competences for lifelong learning" (Vázquez, 2014, p. 59). Little (2001) lists two key benefits of approaching learner autonomy in language classrooms. Firstly, "learning should be more focused and purposeful, and thus more effective both immediately and in the longer term" (p. 8) in the case that the students have chances of participating in the decision-making process. Secondly, once the students become more autonomous and active in their learning, it is reckoned that they will be an effective unit of society. It is inferred to be good inhabitants in the knowledge-based society of the dynamic 21 st century, learners need to extensively rely on their own cognitive and behavioral management. They need to build up their own potential capacities and skills such as creativity, critical thinking, social responsibility, decision-making and problem-solving skills because the language learning process is purposely framed through learners' own reflection on how they learn and manage their learning strategies (Al-Asmari, 2013). In encapsulation, the success of foreign language acquisition is decided by a great extent to learner autonomy both to take initiative in the classroom and persist in their learning path outside the classroom (H. D. Brown, 2007).

It is generally accepted that most teachers would agree that the goal and significance of teaching is to bring about changes in learners. However, Voller (1997) advocates that what those changes might be, and how they can be effectively brought about, are determined by what the learner and the teacher perceive their respective roles to be. Therefore, it is clear that the teacher's role in fostering learner autonomy must be well considered. Teachers who want to foster the autonomy of the language learners should not see themselves as an authority of classroom learning or as a transmitter of knowledge to be poured into the heads of the learners (T. P. T. Nguyen, 2019). To support, learner autonomy does not mean that the teacher becomes redundant in their students' learning process. Instead of that, teachers change their role from a source of information to a counselor, a manager and active participants of learning resources (Duong, 2015). 
There is no doubt that teachers have a vital role in the development of learner autonomy, but learners are seen as the heart of developing this approach. Different scholars have described typical traits of independent learners such as Wenden (1991), Nunan (1997), Littlewood (1999), and Benson (2011), Riihimäki (2013). An autonomous learner refers to "someone who is able to reflect on his or her own learning, takes initiative towards their own learning, sets goals and evaluates their own progress" (Riihimäki, 2013, p. 21). To do this, Wenden (1991) says that learners must handle metacognitive strategies (e.g., planning, monitoring, and evaluating) which enable learners to self-monitor their learning process. Furthermore, Benson (2011) supplements that an autonomous learner not only performs the actions in connection with selfmanagement and cognitive capacities, but also gets involved in making a choice of learning content. In the same fashion, Littlewood (1999) states that to become a fully autonomous learner, the students need to take several responsibilities such as deciding on learning objectives, selecting learning methods, and evaluating the process. Interestingly, Nunan (1997) admits that features of an autonomous learner (e.g., taking initiative, self-evaluation and modifying the tasks) have genuinely existed in the language classrooms especially with really good learners, but these features need to be fostered and catered more among students.

In Vietnam, learners are no longer passive knowledge receivers but look forward to being more active and independent individuals these days, ultimately recognized by Dang (2012), Duong (2015), T. N. Nguyen (2014), and T. P. T. Nguyen (2019). In all probability, they may recognize the importance of learner autonomy, and better achievements of autonomous learners in their language learning these days. In addition, despite of the overabundance of research investigating learner autonomy in general, and the English-majored students' evaluations and perceptions of their autonomous language learning may differ according to sociocultural settings. In addition, these foregoing Vietnamese studies might not exploit three constructs of learner autonomy (i.e., responsibilities, abilities, behaviors) in a very detailed way. Predominantly, the main aim of this paper was to scrutinize the English-majored students' appraisal of their autonomous responsibilities, abilities, and behaviors both inside and outside the class at Hung Vuong University, Vietnam. Thereby, the research question was formed as follows:

How do the English-majored students appraise their autonomous responsibilities, abilities, and behaviors at Hung Vuong University?

\section{Methodology}

\subsection{Research site}

The study was conducted at Hung Vuong University, located at 736 Nguyen Trai Street, Ward 11, District 5, Ho Chi Minh City, Vietnam. Established from the policy of education socialization, Hung Vuong University has continuously been investing and developing to become a high-quality university that reaches both national and international standards for over 20 years. The general English-majored curriculum for the English-majored students consists of a total of 144 credits excluding Vietnamese-driven courses (the latest version), in which 56 credits are framed for sharpening language skills such Effective Listening (14 credits), Communication in English (14 credits), Critical Reading (14 credits) and Critical Writing (14 credits). Besides, the English-majored students take five to six specialization-related courses, equivalent to $12-15$ credits. 


\subsection{Sampling and research participants}

Thanks to the convenience sampling technique, the researcher surveyed 80 Englishmajored students at Hung Vuong University. The reason behind employing this sampling technique was due to "where members of the target population that meet certain practical criteria like easy accessibility, geographical proximity, availability at a given time, or willingness to participate" (Etikan, Musa, \& Alkassim, 2016, p. 1). Of 80 participants, there were 61 females, registering at $76.25 \%$, and 19 males, making up $23.75 \%$. Their age range varied from 19 to 22 .

\subsection{Research design}

To garner data for the posed research questions, the study adopted features of a survey research design. By definition, a survey is "a procedure in quantitative research in which investigators administer a survey to a sample or to the entire population of people to describe attitudes, opinions, behaviors, or characteristics of the population. [...] collect quantitative, numbered data using a questionnaire [...]" (Creswell, 2012, p. 376). Functionally, a survey could help the researcher explore 80 English-majored students' appraisal of their own learner autonomy constructs.

\subsection{Research instrument: Questionnaire}

Under such a survey research design, the researcher determined to utilize a questionnaire which is known to be one of the simplest methods to govern, especially with a large number of subjects (Dörnyei, 2010), and one of the most convenient tools to investigate the target subjects' personal judgments, appraisals, attitudes, beliefs and perceptions (J. D. Brown, 2001). The reliable 28-item questionnaire, whose Cronbach's Alpha values were greater than 0.700 (Pallant, 2005), consisted of three discrete sections. These items were rated on a five-point Likert-scale, including 1: totally disagree, 2: disagree, 3: uncertain, 4: agree, and 5: totally agree. As observed in Table 1, the researcher designed the questionnaire involving three distinct constructs of learner autonomy, that is, responsibilities, abilities, and behaviors as well. These constructs were reflected in different aspects such as temporal dimension (e.g., before, during, after the courses), spatial dimension (e.g., inside and outside the class), or interactional patterns (e.g., with self, with a teacher, with other students).

\section{Table 1}

Description of the questionnaire

\begin{tabular}{|c|c|c|c|}
\hline Construct & Items & $\begin{array}{c}\text { Cronbach's } \\
\text { Alpha }\end{array}$ & Description \\
\hline $\begin{array}{l}\text { Appraisal of } \\
\text { Autonomous } \\
\text { Responsibilities }\end{array}$ & $1-10$ & 0.721 & $\begin{array}{l}\text { This construct was reflected in three temporal } \\
\text { periods of the courses: Before the courses/ } \\
\text { lessons (e.g., identifying objectives, identifying } \\
\text { weaknesses); During the courses/lessons (e.g., } \\
\text { choosing materials, choosing learning } \\
\text { strategies, choosing learning activities); After } \\
\text { the courses/lessons (e.g., evaluating learning } \\
\text { outcomes). }\end{array}$ \\
\hline
\end{tabular}




\begin{tabular}{lccl}
\hline \multicolumn{1}{c}{ Construct } & Items & $\begin{array}{c}\text { Cronbach's } \\
\text { Alpha }\end{array}$ & \multicolumn{1}{c}{ Description } \\
\hline $\begin{array}{l}\text { Appraisal of } \\
\text { Autonomous } \\
\text { Abilities }\end{array}$ & $11-17$ & 0.803 & $\begin{array}{l}\text { This construct involved choosing learning } \\
\text { objectives, choosing learning materials, } \\
\text { choosing learning activities, choosing learning } \\
\text { strategies, which were appraised in both } \\
\text { milieus of language learning, including inside } \\
\text { classroom and outside the classroom. } \\
\text { This construct focused on two places, i.e., } \\
\text { inside and outside the class. In respect of in- } \\
\text { class autonomous behaviors, learning actions } \\
\text { with themselves, with teachers and with } \\
\text { classmates were clarified. Besides, out-of-class } \\
\text { behaviors were pertinent to the students' } \\
\text { completion of assignments and further } \\
\text { practices. }\end{array}$ \\
$\begin{array}{l}\text { Appraisal of } \\
\text { Autonomous }\end{array}$ & $18-28$ & 0.715 & \\
Behaviors & & & \\
Outside) & & &
\end{tabular}

Source: The researcher's data analysis

\subsection{Collection procedure and analysis configuration}

Initially, a consent form was delivered to the Vice Dean of the Faculty of Foreign Languages of Hung Vuong University to inquire about his permission and to assure ethical considerations. Afterward, the Vietnamese questionnaire copies were sent to all 80 participants on the accepted dates. Through preliminarily checking the collected questionnaires from the respondents, the researcher found out that all these 80 copies were valid and accepted, making up 100\%. Eventually, the researcher employed Statistical Package for the Social Sciences (SPSS) version 22.0 to release the descriptive statistics of the garnered questionnaires in terms of percentage (P, \%), mean (M) and standard deviation (S.D.). Peculiar to mean value, the researcher interpreted the participants' responses to the questionnaire items based on Pallant (2005)'s descriptors, that is, 1.00-1.80: strongly disagree; 1.81-2.60: disagree; 2.61- 3.40: moderately agree; 3.41-4.20: highly agree; 4.21-5.00: strongly agree.

\section{Results and discussion}

\subsection{The English-majored students' appraisal of their autonomous responsibilities}

It is necessarily important for English-majored students to identify responsibilities by themselves. Consequently, academic achievement can be fruitfully attained, and ideal autonomous learners can be truly formulated. In order to turn out to be ideal autonomous learners, language learners need to take on an array of responsibilities such as deciding on learning objectives, selecting learning methods, and evaluating process (Littlewood, 1996). According to Scharle and Szabó (2000), a higher magnitude of learner autonomy increases when a sense of responsibility is considerably developed among language learners themselves. Apropos of this conjecture, an appraisal of the English-majored students' responsibilities in their autonomous learning is critical, of which the results are presented in Table 2. 


\section{Table 2}

The English-majored students' appraisal of their autonomous responsibilities

\begin{tabular}{|c|c|c|c|c|c|c|c|c|c|}
\hline Item & Appraised Autonomous Responsibiliti & & TD* & D* & $\mathbf{U}^{*}$ & $\mathbf{A}^{*}$ & TA* & $\mathbf{M}$ & S.D. \\
\hline 1 & $\begin{array}{l}\text { Identifying learning objectives of } \\
\text { courses }\end{array}$ & $\mathbf{P}$ & $0.0 \%$ & $0.0 \%$ & $12.5 \%$ & $31.3 \%$ & $56.3 \%$ & 4.44 & 0.71 \\
\hline 2 & Choosing learning materials & $\mathbf{P}$ & $\begin{array}{c}10.0 \\
\%\end{array}$ & $16.3 \%$ & $25.0 \%$ & $28.7 \%$ & $20.0 \%$ & 3.33 & 1.25 \\
\hline 3 & $\begin{array}{l}\text { Choosing learning methods and } \\
\text { strategies }\end{array}$ & $\mathbf{P}$ & $3.8 \%$ & $10.0 \%$ & $5.0 \%$ & $56.3 \%$ & $25.0 \%$ & 3.89 & 1.02 \\
\hline 4 & Choosing learning activities and tasks & $\mathbf{P}$ & $6.3 \%$ & $6.3 \%$ & $15.0 \%$ & $31.3 \%$ & $41.3 \%$ & 3.95 & 1.18 \\
\hline 5 & Being diligent & $\mathbf{P}$ & $0.0 \%$ & $2.5 \%$ & $6.3 \%$ & $10.0 \%$ & $81.3 \%$ & 4.70 & 0.70 \\
\hline 6 & $\begin{array}{l}\text { Identifying weaknesses and strengths } \\
\text { of my English skills and knowledge }\end{array}$ & $\mathbf{P}$ & $\begin{array}{c}10.0 \\
\%\end{array}$ & $2.5 \%$ & $13.8 \%$ & $43.8 \%$ & $30.0 \%$ & 3.81 & 1.19 \\
\hline 7 & Evaluating my own learning progress & $\mathbf{P}$ & $7.5 \%$ & $7.5 \%$ & $22.5 \%$ & $26.3 \%$ & $36.3 \%$ & 3.76 & 1.24 \\
\hline
\end{tabular}

(*) TD: Totally disagree, D: Disagree, U: Uncertain, A: Agree, TA: Totally agree Source: The researcher's data analysis

As Table 2 illustrates, the majority of the English-majored students at Hung Vuong University positively perceived responsibilities in their autonomous language learning. By the highest mean index (Item 5, M = 4.70, S.D. = 0.70), nearly all of the informants recognized their responsibility to be diligent while learning English (81.3\% totally agree, $10.0 \%$ agree). By the second highest mean score (Item $1, \mathrm{M}=4.44$, S.D. $=0.71$ ), beyond four-fifths of the target sample accepted their responsibility to identify learning objectives of the given English courses (56.3\% totally agree, $31.3 \%$ agree).

Besides, four other autonomous learning responsibilities were also concurred by a big part of the target sample. For instance, above four-fifths of the target sample acknowledged their autonomous responsibility to choose learning methods and strategies (Item $3, \mathrm{M}=3.89$, S.D. $=1.02,25.0 \%$ totally agree, $56.3 \%$ agree). Moreover, the responsibility to choose learning activities and tasks in autonomous language learning was concurred by approximately three quarters of the response community (Item $4,41.3 \%$ totally agree, $31.3 \%$ agree, $\mathrm{M}=3.95$, S.D. $=1.18$ ). What is more, approximately three quarters of the target sample also thought about their autonomous responsibility to identify weaknesses and strengths of my English skills and knowledge (Item 6, 30.0\% totally agree, $43.8 \%$ agree, $M=3.81$, S.D. $=1.19$ ). In addition, for Item $7(\mathrm{M}=3.76, \mathrm{~S} . \mathrm{D} .=1.24)$, the autonomous responsibility to evaluate their own learning progress was also discerned by about two-thirds of the response community $(36.3 \%$ totally agree, $26.3 \%$ agree).

However, only half of the total sample (48.7\%) admitted choosing learning materials as one autonomous responsibility which had to be taken by them (Item 2, M = 3.33, S.D. $=1.25$, $20.0 \%$ totally agree, $28.7 \%$ agree).

As the first consideration, a large number of the English-majored students viewed studying effortfully as their predominant responsibility. Actually, when studiousness and earnestness are persistent, the learners' exposure to language knowledge and skills become 
more intensive. To support it, Scharle and Szabó (2000) tally that learning progress originates from the language learners' own continuing efforts. Secondly, the greater number of the respondents adopted their responsibilities to identify learning goals, to choose learning strategies and methods, to choose learning tasks and activities, and to evaluate their learning progress as well. Inherently, learner autonomy meaningfully takes place if those who actively take responsibility for their objectives, content, progress, method and techniques of learning and the evaluation of the learning process (Duong, 2015; Macaro, 1997; Rivers \& Golonka, 2009). Put simply, it might be a positive result that many English-majored students encouraged these autonomous responsibilities under their overall appraisal. However, some members of the target sample seemed to disregard their autonomous responsibility to choose learning materials or content. As documented earlier by Macaro (1997), and Rivers and Golonka (2009), autonomous learners have to take their responsibility to determine contents (e.g., learning materials) when they participate in any learning course. In addition, learning content is one of the most prominent elements in autonomous learning because it is believed that if a learner can control learning activities but not learning content, they may fail to be a fully autonomous learner (Duong, 2015). Correspondingly, the English lecturers at Hung Vuong University are expected to undertake their facilitating roles to help their English-majored students to accomplish this autonomous responsibility due to the fact that an overwhelming quantity of different learning materials and resources to study come into existence.

\subsection{The English-majored students' appraisal of their autonomous abilities}

Omaggio (1978) supposes that autonomous learners have insights and abilities into their learning strategies and instructional activities in all possibilities. Similarly, autonomous learners are assumed to have their own abilities to self-plan, self-manage, self-regulate and selfassess their study path (Little, 2001; Wenden, 1991). As far as autonomous abilities were concerned, to what extent the English-majored students formulated their autonomous abilities in their language learning, therefore, is illuminated in this section (Table 3).

\section{Table 3}

The English-majored students' appraisal of their autonomous abilities

\begin{tabular}{|c|c|c|c|c|c|c|c|c|c|}
\hline Item & Appraised Autonomous Abiliti & & TD* & $\mathbf{D}^{*}$ & $\mathbf{U}^{*}$ & $\mathbf{A}^{*}$ & TA* & $\mathbf{M}$ & S.D. \\
\hline 8 & $\begin{array}{l}\text { Identifying my objectives inside } \\
\text { the class }\end{array}$ & $\mathbf{P}$ & $3.8 \%$ & $5.0 \%$ & $13.8 \%$ & $31.3 \%$ & $46.3 \%$ & 4.11 & 1.07 \\
\hline 9 & $\begin{array}{l}\text { Identifying my objectives outside } \\
\text { the class }\end{array}$ & $\mathbf{P}$ & $7.5 \%$ & $10.0 \%$ & $18.8 \%$ & $25.0 \%$ & $38.8 \%$ & 3.78 & 1.27 \\
\hline 10 & $\begin{array}{l}\text { Choosing learning materials } \\
\text { inside the class }\end{array}$ & $\mathbf{P}$ & $1.3 \%$ & $3.8 \%$ & $7.5 \%$ & $26.3 \%$ & $61.3 \%$ & 4.43 & 0.88 \\
\hline 11 & $\begin{array}{l}\text { Choosing learning materials } \\
\text { outside the class }\end{array}$ & $\mathbf{P}$ & $13.8 \%$ & $10.0 \%$ & $38.8 \%$ & $28.7 \%$ & $8.8 \%$ & 3.09 & 1.14 \\
\hline 12 & $\begin{array}{l}\text { Choosing learning strategies } \\
\text { inside the class }\end{array}$ & $\mathbf{P}$ & $3.8 \%$ & $8.8 \%$ & $6.3 \%$ & $25.0 \%$ & $56.3 \%$ & 4.21 & 1.13 \\
\hline 13 & $\begin{array}{l}\text { Choosing learning strategies } \\
\text { outside the class }\end{array}$ & $\mathbf{P}$ & $13.8 \%$ & $17.5 \%$ & $31.3 \%$ & $26.3 \%$ & $11.3 \%$ & 3.04 & 1.21 \\
\hline
\end{tabular}




\begin{tabular}{|c|c|c|c|c|c|c|c|c|c|}
\hline Item & Appraised Autonomous Abiliti & & TD* & $\mathbf{D}^{*}$ & $\mathbf{U}^{*}$ & A* & $\mathbf{T A} *$ & $\mathbf{M}$ & S.D. \\
\hline 14 & $\begin{array}{l}\text { Choosing learning activities inside } \\
\text { the class }\end{array}$ & $\mathbf{P}$ & $8.8 \%$ & $6.3 \%$ & $13.8 \%$ & $26.3 \%$ & $45.0 \%$ & 3.93 & 1.28 \\
\hline 15 & $\begin{array}{l}\text { Choosing learning activities } \\
\text { outside the class }\end{array}$ & $\mathbf{P}$ & $7.5 \%$ & $13.8 \%$ & $26.3 \%$ & $40.0 \%$ & $12.5 \%$ & 3.36 & 1.11 \\
\hline 16 & $\begin{array}{l}\text { Identifying weaknesses and } \\
\text { strengths of my English skills and } \\
\text { knowledge }\end{array}$ & $\mathbf{P}$ & $6.3 \%$ & $5.0 \%$ & $16.3 \%$ & $27.5 \%$ & $45.0 \%$ & 4.00 & 1.18 \\
\hline 17 & $\begin{array}{l}\text { Evaluating my own learning } \\
\text { progress }\end{array}$ & $\mathbf{P}$ & $7.5 \%$ & $10.0 \%$ & $7.5 \%$ & $21.3 \%$ & $53.8 \%$ & 4.04 & 1.31 \\
\hline
\end{tabular}

(*) TD: Totally disagree, D: Disagree, U: Uncertain, A: Agree, TA: Totally agree

Source: The researcher's data analysis

As evidenced in Table 3, the majority of the participants confidently appraised that they possessed autonomous ability to identify their learning objectives inside the class (Item $8, \mathrm{M}=$ 4.11, S.D. $=1.07,46.3 \%$ totally agree, $31.3 \%$ agree) and outside the class (Item $9, \mathrm{M}=3.78$, S.D. $=1.27,38.8 \%$ totally agree, $25.0 \%$ agree). Yet, this autonomous ability inside the class appeared to be better performed than that outside the class, proven by mean comparison.

In addition, the majority of the participants were confident of their ability to choose learning materials inside the class (Item 10, 61.3\% totally agree, 26.3\% agree) while only the minority of the entire sample admitted this ability outside the class (Item 11, 8.8\% totally agree, $28.7 \%$ agree). This disparity was also evidently observed by mean compassion, Item $10(\mathrm{M}=$ 4.43, S.D. $=0.88)$ compared to Item $11(\mathrm{M}=3.09$, S.D. $=1.14)$.

While more than $80 \%$ of the sample confessed their autonomous ability to choose learning strategies or methods inside the classroom (Item 12, 56.3\% totally agree, $25.0 \%$ agree, $\mathrm{M}=4.21$, S.D. $=1.13$ ), only one-third of the entire sample agreed with this ability outside the class (Item 13, M = 3.04, S.D. $=1.21,11.3 \%$ totally agree, $26.3 \%$ agree).

Likewise, there is a plight that the ability to choose learning activities and tasks inside the class outperformed outside the class with reference to percentage and mean comparisons. Statistically, the former was appraised by roughly three quarters of the whole sample (Item 14, $\mathrm{M}=3.93$, S.D. $=1.28,45.0 \%$ totally agree, $26.3 \%$ agree); whereas, the latter was clarified by around half of the total sample (Item 15, M=3.36, S.D. $=1.11,12.5 \%$ totally agree, $40.0 \%$ agree).

What is more, about three quarters of the response community acknowledged their autonomous ability to identify flaws and strengths of their English skills and knowledge (Item $16, \mathrm{M}=4.00$, S.D. $=1.18,45.0 \%$ totally agree, $27.5 \%$ agree) and autonomous ability to evaluate their own learning progress (Item 17, M = 4.04, S.D. = 1.31, 53.8\% totally agree, $21.3 \%$ agree).

In respect of the autonomous ability construct, there existed a paradox among the English-majored students that autonomous abilities inside the class were superior to outside the class. Overall, compared to the English-majored students' high appraisal of autonomous responsibilities as mentioned above, their autonomous abilities were confined to some extent, especially outside the class. Coupled with the descriptive statistics, the results from some 
private talks revealed that this discrepancy stemmed from the presence of the language teachers in the classroom, the crystal clear prescription of the syllabi within all-inclusive objectives, strategies, activities and materials, along with the teachers' useful instructions and suggestions inside the class. Theoretically, Littlewood (1996) believes that language learners are inherently the owner of an assemblage of inner autonomous abilities to mold their own learning both inside and outside the class. However, "learner autonomy is an achievement, attained interrelationally between the learner and the teacher" (Ganza, 2008, p. 65). In other words, teachers are assumed to play a critical role in stimulating the autonomous learning abilities, helping learners to develop self-efficacy, self-confidence, motivation and abilities (e.g., knowledge and skills) so that they can learn the language courses independently, and become autonomous individuals in any learning circumstance (Littlewood, 1996). Thus, it is expected that the language learners' autonomous abilities outside class may be accumulated within the teachers' support, guide and tutor where necessary. On the contrary, without the teacher's support and guide, the autonomous learning process may get low efficiency or even fall into disorder (Duong, 2015). Briefly, the English-majored students' holistic autonomous abilities can be effectively developed providing that their language teachers at Hung Vuong University must take a wide variety of roles like counselor, tutor, manager and active participants (Duong, 2015; T. N. Nguyen, 2014; T. P. T. Nguyen, 2019) regardless the temporal and spatial traits.

\subsection{The English-majored students' appraisal of their autonomous behaviors}

In both theory and practice, learner autonomy can happen both inside and outside the class (Sinclair, 2000) under different activity configurations and interactional patterns (Duong, 2015; T. P. T. Nguyen, 2019). Furthermore, it is widely assumed that autonomous learning behaviors can be reflected in the interactional patterns between language learners and their teachers, and their classmates, and especially themselves. This section, purposely, depicts the crystal clear portrayal of what and how the autonomous behaviors were taken by the Englishmajored students at Hung Vuong University inside (Table 4) and outside (Table 5) the class.

\section{Table 4}

The English-majored students' appraisal of their autonomous behaviors inside the class

\begin{tabular}{|c|c|c|c|c|c|c|c|c|c|}
\hline Item & $\begin{array}{c}\text { Appraised Autonomous Behavio } \\
\text { Inside the Class }\end{array}$ & & TD* & D* & $\mathbf{U}^{*}$ & $\mathbf{A}^{*}$ & TA* & $\mathbf{M}$ & S.D. \\
\hline 18 & $\begin{array}{l}\text { Taking notes of the ongoing } \\
\text { lessons }\end{array}$ & $\mathbf{P}$ & $6.3 \%$ & $5.0 \%$ & $13.8 \%$ & $31.3 \%$ & $43.8 \%$ & 4.01 & 1.16 \\
\hline 19 & $\begin{array}{l}\text { Working collaboratively with my } \\
\text { classmates }\end{array}$ & $\mathbf{P}$ & $7.5 \%$ & $10.0 \%$ & $18.8 \%$ & $25.0 \%$ & $38.8 \%$ & 3.78 & 1.27 \\
\hline 20 & $\begin{array}{l}\text { Asking for support, guide from } \\
\text { my teachers }\end{array}$ & $\mathbf{P}$ & $18.8 \%$ & $15.0 \%$ & $33.8 \%$ & $26.3 \%$ & $6.3 \%$ & 2.86 & 1.19 \\
\hline
\end{tabular}

(*) TD: Totally disagree, D: Disagree, U: Uncertain, A: Agree, TA: Totally agree

Source: The researcher's data analysis

From the descriptive statistics in Table 4, a greater number of the English-majored students experienced their autonomous behavior as taking notes of the ongoing lessons inside the class (Item $18, \mathrm{M}=4.01$, S.D. $=1.16,43.8 \%$ totally agree, $31.3 \%$ agree). In addition, many 
English-majored students of the target sample expressed that they worked collaboratively with their classmates inside the class (Item 19, $\mathrm{M}=3.78, \mathrm{~S} . \mathrm{D} .=1.27,38.8 \%$ totally agree, $25.0 \%$ agree). On the other hand, nearly one-third of the entire sample got contact with their English lecturers for support and guide inside the class (Item 20, M = 2.86, S.D. $=1.19,6.3 \%$ totally agree, 26.3\% agree). Overall, it is reasonable to infer that the English-majored students at Hung Vuong University seemed to prefer working with themselves or with their classmates to interacting with their teachers.

Apropos of the interpreted results, it is clear that many English-majored students of the target sample would rather interact with their classmates or with themselves than get contact with their teachers inside the class. Emphatically, the results from the private talks documented that some students tended to be reticent or reserved, and even afraid of making any mistakes. In response to this unhoped predicament, the English teachers at Hung Vuong University should help the English-majored students diminish these negative psychological indicators. At the same time, they need to shape an exciting and pleasant schooling environment where their language students are provoked to become more active and confident members inside the class. Surmised by Dörnyei (2001), any language teachers' task is to make their learners amplify their self-efficacy, self-confidence and motivation level to learn independently and become autonomous individuals in any learning milieu. And, one of the motivational strategies for language learners' autonomous learning is authorized by teachers who mindfully generate a good rapport with their learners inside the class, encourage them to use language confidently, but focus on the correction. In encapsulation, promoting learner autonomy can be actually successful when there is an interaction between language learners and their teacher regardless of the extent.

\section{Table 5}

The English-majored students' appraisal of their autonomous behaviors outside the class

\begin{tabular}{llllllllllll}
\hline Item & $\begin{array}{l}\text { Appraised Autonomous Behaviors } \\
\text { Outside the Class }\end{array}$ & TD* & $\mathbf{D}^{*}$ & $\mathbf{U}^{*}$ & $\mathbf{A}^{*}$ & $\mathbf{T A} *$ & $\mathbf{M}$ & $\mathbf{S . D .}$ \\
$\mathbf{2 1}$ & $\begin{array}{l}\text { Doing extra activities and tasks } \\
\text { not demanded by my teachers }\end{array}$ & $\mathbf{P}$ & $18.8 \%$ & $21.3 \%$ & $26.3 \%$ & $15.0 \%$ & $18.8 \%$ & 2.94 & 1.37 \\
$\mathbf{2 2}$ & $\begin{array}{l}\text { Listing strengths and weaknesses } \\
\text { of my English skills and } \\
\text { knowledge }\end{array}$ & $\mathbf{P}$ & $7.5 \%$ & $15.0 \%$ & $23.8 \%$ & $42.5 \%$ & $11.3 \%$ & 3.35 & 1.10 \\
$\mathbf{2 3}$ & $\begin{array}{l}\text { Self-practicing English listening } \\
\text { skills via the Internet or audio } \\
\text { programs }\end{array}$ & $\mathbf{P}$ & $8.8 \%$ & $16.3 \%$ & $22.5 \%$ & $31.2 \%$ & $21.3 \%$ & 3.40 & 1.24 \\
$\mathbf{2 4}$ & $\begin{array}{l}\text { Self-practicing English speaking } \\
\text { skills with my friends }\end{array}$ & $\mathbf{P}$ & $6.3 \%$ & $15.0 \%$ & $17.5 \%$ & $30.0 \%$ & $31.2 \%$ & 3.65 & 1.24 \\
$\mathbf{2 5}$ & $\begin{array}{l}\text { Self-practicing English reading } \\
\text { skills via newspapers, magazines }\end{array}$ & $\mathbf{P}$ & $15.0 \%$ & $15.0 \%$ & $27.5 \%$ & $32.5 \%$ & $10.0 \%$ & 3.08 & 1.22
\end{tabular}




\begin{tabular}{|c|c|c|c|c|c|c|c|c|c|}
\hline Item & $\begin{array}{l}\text { Appraised Autonomous Behavior } \\
\text { Outside the Class }\end{array}$ & & TD* & $D^{*}$ & $\mathbf{U}^{*}$ & $\mathbf{A}^{*}$ & TA* & M & S.D. \\
\hline 26 & $\begin{array}{l}\text { Self-practicing English writing } \\
\text { skills via writing tasks on the } \\
\text { Internet }\end{array}$ & $\mathbf{P}$ & $17.5 \%$ & $11.3 \%$ & $36.3 \%$ & $18.8 \%$ & $16.3 \%$ & 3.05 & 1.30 \\
\hline 27 & $\begin{array}{l}\text { Seeking, and doing grammar } \\
\text { exercises }\end{array}$ & $\mathbf{P}$ & $18.8 \%$ & $23.8 \%$ & $23.8 \%$ & $18.8 \%$ & $15.0 \%$ & 2.88 & 1.34 \\
\hline 28 & $\begin{array}{l}\text { Seeking vocabulary resources, and } \\
\text { learning }\end{array}$ & $\mathbf{P}$ & $12.5 \%$ & $10.0 \%$ & $18.8 \%$ & $42.5 \%$ & $16.3 \%$ & 3.40 & 1.24 \\
\hline
\end{tabular}

(*) TD: Totally disagree, D: Disagree, U: Uncertain, A: Agree, TA: Totally agree

Source: The researcher's data analysis

As Table 5 demonstrates that about one-third of the entire response community autonomously completed extra activities and tasks not obliged by their teachers outside the class (Item $21, \mathrm{M}=2.94$, S.D. $=1.37,18.8 \%$ totally agree, $15.0 \%$ agree). However, it might be a positive signal that beyond fifty percent of the total respondents made a list of strengths and limitations of their English skills and knowledge outside the class (Item 22, M = 3.35, S.D. = $1.10,11.3 \%$ totally agree, $42.5 \%$ agree). While speaking, listening and learning vocabulary were favorably practiced by the majority of the participants outside the class, there was an apparent ignorance of other language skills and knowledge, including reading, writing and learning grammar.

On one hand, many students frequently self-practiced English speaking skills with their friends (Item $24, \mathrm{M}=3.65$, S.D. $=1.24,31.2 \%$ totally agree, $30.0 \%$ agree), and self-practiced English listening skills through the Internet or audio programs (Item 23, M $=3.40$, S.D. $=1.24$, $21.3 \%$ totally agree, $31.2 \%$ agree). On the other hand, only some learners had frequently selfpracticed English reading skills through newspapers, magazines and others (Item 25, 10.0\% totally agree, $32.2 \%$ agree, $\mathrm{M}=3.08$, S.D. $=1.22$ ) and self-practice English writing skills through Internet (Item $26, \mathrm{M}=3.05$, S.D. $=1.30,16.3 \%$ totally agree, $18.8 \%$ agree) outside the class.

Notwithstanding many students frequently seeking vocabulary resources and learning vocabulary forms and meanings outside the class (Item 28, M = 3.40, S.D. $=1.24,16.3 \%$ totally agree, $42.5 \%$ agree), only some students frequently accumulated their grammar knowledge via exercises or tasks outside the class (Item 27, M $=2.88$, S.D. $=1.3415 .0 \%$ totally agree, $18.8 \%$ agree).

Autonomous learning inside the class seemed insufficient in terms of time quantity and density; meanwhile, learner autonomy outside the class can make a considerable contribution to higher levels of language proficiency (Benson, 2011; Hsieh \& Hsieh, 2019). Unexpectedly, only some learners actually paid attention to supplementary assignments or tasks outside the class. It is a widely known motto that practice makes perfect. Generally speaking, only in-class activities or tasks are inadequate for language learners to get language skills and knowledge (Duong, 2015), but they should much engage in the process of building their own knowledge and skills outside the class (T. P. T. Nguyen, 2019). Besides, one of the most valuable characteristics of autonomous learners is their ownership of metacognitive 
strategies (e.g., evaluating strategies), assisting them to self-regulate their learning process (Wenden, 1991). Positively, many English-majored students in this study were actively aware of their current English language quality. Until they scrutinize the true caliber of their language proficiency in terms of goodness and flaws, they know how to improve its quality dramatically. In another point, many English majors frequently experienced their autonomous learning behaviors on listening, speaking and learning vocabulary, but they were ignorant of reading, writing and learning grammar outside the class. The results from private talks unveiled that the latter language skills and knowledge were less interesting and applicable. There is no doubt that one person's language proficiency level is fully assessed on all four skills (e.g., listening, speaking, reading and writing) and on language knowledge (e.g., vocabulary and grammar). It means that the participants should reappraise this lack of harmony in their autonomous behaviors outside the class.

\section{Concluding marks}

Although this study faced some limitations such as the time restriction for carrying out the study and the small number of participants, it also yielded remarkable findings as follows. First of all, concerning the construct of responsibilities, a large number of the participants positively recognized their autonomous responsibilities in a variety of learning aspects such as making efforts, identifying learning objectives, choosing learning strategies and activities, evaluating their language and learning progress. Nevertheless, they considered that making a choice of learning contents and materials should be owned by their teachers' responsibilities

and roles. Secondly, with regards to autonomous learning abilities, there was a plight that many learners' autonomous abilities inside class outperformed those outside class due to some convenient ambiance in the class such as the presence of teachers, the crystal clear prescription of language syllabi. Thirdly, with reference to autonomous behaviors inside the class, a big portion of the surveyed learners preferred working with their classmates or with themselves to interacting with their teachers owing to their reticence or shyness. Finally, considering the construct of autonomous behaviors outside the class, it seemed that many learners did not complete selective assignments, self-practice reading, writing and grammar because they perceived that they were impractical and challenging. On the contrary, they would rather spend time self-training listening, speaking and vocabulary. Interestingly, more than half of the learners thought of and made a list of their language strengths and flaws.

\section{References}

Al-Asmari, A. R. (2013). Practices and prospects of learner autonomy: Teachers' perceptions. English Language Teaching Journal, 6(3), 1-10.

Benson, P. (2007). Autonomy in language teaching and learning. Language Teaching, 40(1), $21-40$.

Benson, P. (2011). Teaching and researching autonomy (2nd ed.). London, UK: Pearson Education.

Borg, S., \& Al-Busaidi, S. (2012). Teachers' beliefs and practices regarding learner autonomy. ELT Journal, 66(3), 283-292. 
Brown, H. D. (2007). Teaching by principles: An interactive approach to language pedagogy (3rd ed.). New York, NY: Pearson Longman.

Brown, J. D. (2001). Using surveys in language programs. Cambridge, UK: Cambridge University Press.

Creswell, J. W. (2012). Educational research: Planning, conducting, and evaluating quantitative (4th ed.). Boston, MA: Pearson Education.

Dam, L., Eriksson, R., Little, D., Miliander, J., \& Trebbi, T. (1990). Towards a definition of autonomy. In T. Trebbi (Ed.), Third Nordic workshop on developing autonomous learning in the EFL classroom (pp. 102-103). Bergen, Norway: University of Bergen.

Dang, T. T. (2012). Learner autonomy perception and performance: A study on Vietnamese students in online and offline learning environments (Unpublished doctoral dissertation). La Trobe University, Australia.

Dörnyei, Z. (2001). Motivational strategies in the language classroom. Cambridge, UK: Cambridge University Press.

Dörnyei, Z. (2010). Questionnaires in second language research: Construction, administration, and processing (2nd ed.). London, UK: Routledge.

Duong, M. T. (2015). A portfolio-based learner autonomy development model in an EFL writing course (Unpublished doctoral dissertation). Suranaree University of Technology, Thailand.

Etikan, I., Musa, S. A., \& Alkassim, N. S. (2016). Comparison of convenience sampling and purposive sampling. American Journal of Theoretical and Applied Statistics, 5(1), 1-4.

Ganza, W. L. (2008). Learner autonomy-teacher autonomy. In T. Lamb \& H. Reinders (Eds.), Learner and teacher autonomy: Concepts, realities and responses (pp. 63-79). Amsterdam/Philadelphia: John Benjamin.

Han, L. (2014). Teacher's role in developing learner autonomy: A literature review. International Journal of English Language Teaching, 1(2), 21-27.

Holec, H. (1981). Autonomy and foreign language learning. Oxford, UK: Pergamon Press.

Hsieh, H-C., \& Hsieh, H-L. (2019). Undergraduates' out-of-class learning: Exploring EFL students' autonomous learning behaviors and their usage of resources. Education Science, 9(159), 1-15.

Little, D. (2001). Learner autonomy and the challenge of tandem language learning via the Internet. In A. Chambers \& G. Davis (Eds.), ICT and language learning: A European perspective (pp. 29-38). Amsterdam, Netherlands: Swets \& Zeitlinger Publishers.

Littlewood, W. (1996). “Autonomy”: An anatomy and a framework. System, 24(4), 427-435.

Littlewood, W. (1999). Defining and developing autonomy in East Asian contexts. Applied Linguistics, 20(1), 71-94.

Macaro, E. (1997). Target language, collaborative learning, and autonomy. Clevedon, UK: Multilingual Matters.

Nguyen, T. N. (2014). Learner autonomy in language learning: Teachers' beliefs (Unpublished doctoral dissertation). Queensland University of Technology, Brisbane, Australia. 
Nguyen, T. P. T. (2019). Teachers' beliefs in the necessity and feasibility of fostering learner autonomy in learning writing (Unpublished master's thesis). Ho Chi Minh City Open University, Ho Chi Minh, Vietnam.

Nunan, D. (1997). Designing and adapting materials to encourage learner autonomy. In P. Benson \& P. Voller (Eds.), Autonomy and independence in language learning (pp. 192203). London, UK: Longman.

Omaggio, A. C. (1978). Successful language learners: What do we know about them? ERIC/CLL News Bulletin, 2-3.

Pallant, J. (2005). SPSS survival guide: A step by step guide to data analysis using SPSS for windows (3rd ed.). New York, NY: Open University Press.

Riihimäki, J. (2013). Autonomous language learning in EFL classrooms in Finland: A descriptive study (Unpublished master's thesis). University of Jyväskylä, Finland.

Rivers, W. P., \& Golonka, E. M. (2009). Third language acquisition theory and practice. In M. H. Long \& C. J. Doughty (Eds.), The handbook of language teaching (pp. 250-266). Hoboken, NJ: Blackwell Publishing.

Scharle, A., \& Szabó, A. (2000). Learner autonomy: A guide to developing learner responsibility. Cambridge, UK: Cambridge University Press.

Sinclair, B. (2000). Learner autonomy: The next phase? In B. Sinclair, I. McGrath \& T. Lamb (Eds.), Learner autonomy, teacher autonomy: Future directions (pp. 4-14). Harlow, UK: Longman.

Trinh, Q. L. (2005). Stimulating learner autonomy in English language education: A curriculum innovation study in a Vietnamese context (Unpublished doctoral dissertation). University of Amsterdam, Netherland.

Vázquez, M. B. (2014). Pedagogy for autonomy in FLT: An exploratory analysis on its implementation through case studies. Porta Linguarum, 23, 59-74.

Voller, P. (1997). Does the teacher have a role in autonomous language learning? In P. Benson \& P. Voller (Eds.), Autonomy \& independence in language learning (pp. 98-113). London, UK: Longman.

Wenden, A. L. (1991). Learner strategies for learner autonomy. Hemel Hempstead, UK: Prentice Hall. 